\title{
Effect of Deuterium Depletion on Erythrocytes in Experimental Diabetes
}

\author{
Deneysel Diyabette Döteryum Azlığının Eritrositler Üzerine Etkisi
}

\author{
Arif Çolak ${ }^{1}$, Ayşen Yarat ${ }^{1}$ D , Turay Yardımcı \\ 'Department of Basic Medical Sciences, Biochemistry, Faculty of Dentistry, Marmara University, Istanbul, Turkey \\ ${ }^{2}$ Department of Biochemistry, Faculty of Pharmacy, Girne American University, North Cyprus
}

ORCID ID: A.Y. 0000-0002-8258-6118

Cite this article as: Çolak A, Yarat A, Yardımcı T. Effect of Deuterium Depletion on Erythrocytes in Experimental Diabetes. Experimed 2020; 10(1): 30-7.

\begin{abstract}
In the development of diabetic complications, oxidative stress caused by hyperglycemia plays an important role. Deuterium depletion has protective effect against cellular damage and tumor suppressor effect in cancer cell lines. The purpose of this study was to examine and evaluate the effect of deuterium depletion on erythrocyte oxidant and antioxidant system parameters in experimental diabetes induced by streptozotocin (STZ) in rats. On the $30^{\text {th }}$ or $40^{\text {th }}$ day after STZ injection, blood samples were taken and blood glucose levels were measured. Erythrocyte hemolysates were also prepared. Lipid peroxidation and glutathione levels and glutathione-S-transferase, superoxide dismutase and catalase enzyme activities of erythrocytes were determined. At the 30 or 40 day periods, deuterium depleted water (DDW) consumption had differently affected oxidant-antioxidant parameters of erythrocytes. The clear effect of deuterium depletion in drinking water from $150 \mathrm{ppm}$ to $85 \mathrm{ppm}$ was observed in glutathione levels and it increased erythrocyte glutathione levels in both the control and diabetic groups. In conclusion, deuterium depletion may have protective effects on diabetes induced oxidative stress. Further studies are needed to be done to determine the mechanism of action and the useful dosage and the application period of DDW.
\end{abstract}

Keywords: Experimental diabetes, erythrocyte, deuterium depletion, antioxidant and oxidant parameters

\section{INTRODUCTION}

The mass difference between the two stable isotopes, hydrogen and deuterium, leads to differences in their physical and chemical behavior $(1,2)$. The effect of hydrogen replacing with deuterium in the biological systems has also been well documented $(3,4)$. To date, the effects of deuterium in organisms has focused mainly on deuterated water;

\section{öz}

Diabetik komplikasyonların gelişmesinde, hiperglisemi kaynaklı oksidatif stres çok önemli bir rol oynamaktadır. Döteryum azlığının hücresel hasara karşı ve tümör baskılayıcı etki üzerine koruyucu etkisi olduğu kanser hücre hatlarında gösterilmiştir. Çalışmanın amacı, döteryum azaltılmasının sıçanlarda streptozotosin (STZ) ile oluşturulmuş deneysel diabette eritrosit oksidan ve antioksidan sistem parametreleri üzerindeki etkisinin araştırılması ve değerlendirilmesidir. STZ enjeksiyonunu takiben 30. veya 40 . günde, kan örnekleri alınıp, kan glukoz değerleri ölçülmüş, eritrosit hemolizatIarı da hazırlanmıştır. Eritrositlerin lipid peroksidasyon ve glutatyon seviyeleri ile glutatyon-S-transferaz, süperoksit dismutaz ve katalaz enzim aktiviteleri tayin edilmiştir. 30 veya 40 günlük periyotlardaki döteryumu azaltılmış su tüketiminin, eritrosit oksidan-antioksidan parametre düzeylerine etkisinin farklı olduğu görülmüştür. İçme suyunda döteryumun 150 ppm den 85 ppm'e azaltılmasının net etkisi glutatyon düzeylerinde gözlenmiş olup hem kontrol hem de diyabetik gruplarda eritrosit glutatyon düzeylerini artırdığı saptanmıştır. Sonuç olarak, döteryumu azaltılmış suyun, diabete bağlı oksidatif hasara karşı koruyucu etkisi olabilir. Döteryumu azaltılmış suyun etki mekanizmasının, uygun dozunun ve uygulama süresinin aydınlatılması için daha fazla çalışmalara ihtiyaç vardır.

Anahtar Kelimeler: Deneysel diabet, eritrosit, döteryum azlığı, antioksidan ve oksidan parametreler

however few studies have been conducted on deuterium depletion.

Deuterium concentration is approximately $150 \mathrm{ppm}$ in healthy human blood and it can be changed by age and sex. Drinking waters have different deuterium concentrations because of geographical differentiations. This situation causes different deuterium concentrations in blood 
and urine (5-7). Usage of deuterium-depleted water (DDW) has had growing interest recently.

It has been revealed that, deuterium is essential for normal growth of animal and plant cells (7-9). Inhibition of cell proliferation and increased apoptosis by the effect of DDW have been shown in some in vitro studies. It has been also shown in some animal experiments that growth of tumor cells is decreased by DDW (10-13). However, a slight increase in deuterium concentration has caused stimulation to growing of tumor cells $(14,15)$.

An increased production of reactive oxygen species in diabetes mellitus is associated with a reduction in antioxidant defenses. Streptozotocin (STZ) has been widely used to induce diabetes. Selective destruction of pancreatic B cells, probably because of a free radical-mediated mechanism, occurs (16). During the reduction of $\mathrm{O}_{2}$, free radicals are formed, such as peroxyl, hydrox$\mathrm{yl}$, and superoxide radicals, which either directly or indirectly cause cell damage.

Erythrocyte membrane tightness and antioxidant enzyme activities are also altered in diabetes mellitus (17-19).

Few studies related with deuterium depletion and diabetes are present in the literature $(8,20,21)$. Reduction or stabilization of blood sugar levels has been reported in diabetic patients who were consuming DDW $(5,20,21)$. However, there have not been any reports on the effect of DDW consumption on erythrocytes of diabetic patients in the literature.

In this study, the effect of deuterium depletion on erythrocytes was investigated. Lipid peroxidation (LPO) and glutathione (GSH) levels, glutathione-S-transferase (GST), superoxide dismutase (SOD) and catalase (CAT) activities were determined in the erythrocyte hemolysates of the normal and diabetic rats given DDW.

\section{MATERIAL AND METHOD}

The study was approved by the Animal Ethics Committee of Marmara University (Registration no: 52.2008.mar). A total of 40 rats (Sprague Dawley) of either sex (240-485 g) were obtained from the animal house facility of Marmara University. They were maintained under standard laboratory conditions at $20 \pm 2{ }^{\circ} \mathrm{C}$, relative humidity ( $50 \pm 15 \%$ ) and normal photoperiod (12-hour light-dark cycle) for the duration of the experiment. A commercial pellet diet (Coban Cesme Animal Food Factory, Istanbul, Turkey) and water were provided ad libitum.

Animals were divided into six groups of G1, G2, G3 as the controls and G4, G5, G6 as the diabetics. To every diabetic group, a single dose of $35 \mathrm{mg} / \mathrm{kg} \mathrm{STZ} \mathrm{(Sigma,} \mathrm{St.} \mathrm{Louis,} \mathrm{Mo,} \mathrm{USA),} \mathrm{freshly}$ dissolved in citrate buffer ( $\mathrm{pH}: 4.5$ ) was injected intraperitoneally and blood glucose was checked two days later. Tap water was given to one of control and diabetic groups (G1 and G4). DDW (Preventa, Hungary) was given to $\mathrm{G} 2$ and $\mathrm{G} 5$ groups 10 days before diabetes improvement and to $\mathrm{G} 3$ and $\mathrm{G} 6$ groups after diabetes improvement. Deuterium concentration of tap water and DDW were around 150 and 85 ppm respectively. Deuterium concentration of tap water samples was determined in the Government Stable Isotope Laboratory in Ankara.

On the $30^{\text {th }}$ or $40^{\text {th }}$ day of diabetes induction, blood samples were collected from the hearts of the control and diabetic groups of rats under ether anesthesia. 10\% erythrocyte hemolysate was prepared. Blood glucose levels were determined according to glucose oxidase method. Antioxidant enzymes activities, namely GST, (22) CAT, (23) SOD (24) and for LPO, (25) and GSH (26) levels were determined in erythrocytes hemolysates.

Statistical analysis was carried out using SPSS 18.0. All data were expressed as mean \pm standard deviation. In statistical analysis, Mann-Whitney U test, Kruskal Wallis test, Kolmogorov Smirnov test, Levene test, ANOVA test, Tukey test, Welch test or Dunnett T3 were applied. P values less than 0.05 were considered to be significant.

\section{RESULTS}

Prior to diabetes induction, blood glucose levels and body weights were not significantly different between all of the groups ( $p>0.05$ ). Two days after STZ injection, blood glucose levels of diabetic groups (G4, G5 and G6) were significantly higher than their initial levels $(p<0.05)$. Therofore, animals of these groups were accepted as diabetic.

\section{Comparison of Control and Diabetic Groups}

No significant differences were found in the body weights between control and diabetic groups at the end of the experiment. However, food and water consumption and blood glucose levels were significantly increased (Table 1). The blood glucose levels after two days of STZ injection were also significantly higher than those of the controls.

Comparison between groups in point of erythrocyte parameters was also seen in Table 1. No significant differences were present in GST activities between control and diabetic groups. In the diabetic groups, Hb levels were increased and LPO levels and SOD activities were decreased significantly compared to the controls. Erythrocyte GSH levels, CAT and SOD activities were significantly decreased in tap water drinking and 30 days DDW drinking diabetic groups $(G 4, G 5)$ compared to matched controls (G1 and G2). However, GSH was significantly increased, SOD was significantly decreased and CAT was not significantly changed in 40 days DDW drinking diabetic group (G6) compared to 40 days tap water drinking control group (G3) (Table 1).

\section{Effect of DDW in Control Group}

Blood glucose levels and body weights were not affected by DDW consumption. Food and DDW consumptions were greater than those in tap water drinking control and diabetic groups (Table 2).

DDW consumption did not cause any change in erythrocyte GST activities in the control groups. However, it caused signifi- 
Table 1. Comparison of food and water consumption, body weight, blood glucose levels and erythrocytes parameters in control and diabetic groups.

\begin{tabular}{|c|c|c|c|}
\hline & $\begin{array}{l}\text { Control Group } \\
\text { (G1) }(n=6)\end{array}$ & $\begin{array}{l}\text { Diabetic Group } \\
\text { (G4) }(n=6)\end{array}$ & $\mathbf{P}$ \\
\hline Weight (gr) & $350.83 \pm 78.89$ & $294.50 \pm 85.54$ & 0.263 \\
\hline Food (gr/day) & $24.61 \pm 0.0$ & $29.44 \pm 0.0$ & 0.001 \\
\hline Tap Water (ml/day) & $36.22 \pm 0.0$ & $89.11 \pm 0.0$ & 0.001 \\
\hline Blood glucose (mg\%) & $109.50 \pm 6.44$ & $270.61 \pm 28.53$ & 0.0001 \\
\hline $\mathrm{Hb}(\mathrm{gr} \%)$ & $2.18 \pm 0.13$ & $2.87 \pm 0.16$ & 0.0001 \\
\hline LPO $(\mu \mathrm{mol} \mathrm{MDA} / \mathrm{gr} \mathrm{Hb})$ & $0.28 \pm 0.04$ & $0.23 \pm 0.02$ & 0.009 \\
\hline $\mathrm{GSH}(\mu \mathrm{mol} / \mathrm{gr} \mathrm{Hb})$ & $0.41 \pm 0.11$ & $0.11 \pm 0.03$ & 0.0001 \\
\hline GST (U/gr Hb) & $2.75 \pm 1.53$ & $2.82 \pm 1.28$ & 0.935 \\
\hline CAT (kU/gr Hb) & $216.07 \pm 16.65$ & $167.50 \pm 8.62$ & 0.0001 \\
\hline \multirow[t]{2}{*}{$\mathrm{SOD}(\mathrm{U} / \mathrm{mg} \mathrm{Hb})$} & $1.91 \pm 0.50$ & $1.24 \pm 0.41$ & 0.030 \\
\hline & $\begin{array}{c}\text { Control + } \text { DDW }_{30} \\
\text { (G2) }(n=6)\end{array}$ & $\begin{array}{c}\text { Diabetic }+\mathrm{DDW}_{30} \\
\text { (G5) }(\mathrm{n}=8)\end{array}$ & $\mathbf{P}$ \\
\hline Weight (gr) & $340.00 \pm 80.25$ & $266.88 \pm 62.68$ & 0.079 \\
\hline Food (gr/day) & $26.39 \pm 0.0$ & $28.92 \pm 0.0$ & 0.001 \\
\hline DDW (ml/day) & $45.17 \pm 0.0$ & $98.67 \pm 0.0$ & 0.001 \\
\hline Blood Glucose (mg\%) & $97.33 \pm 11.96$ & $204.38 \pm 26.70$ & 0.0001 \\
\hline $\mathrm{Hb}(\mathrm{gr} \%)$ & $1.70 \pm 0.15$ & $3.11 \pm 0.07$ & 0.0001 \\
\hline LPO $(\mu \mathrm{mol} \mathrm{MDA} / \mathrm{gr} \mathrm{Hb})$ & $0.27 \pm 0.04$ & $0.14 \pm 0.01$ & 0.0001 \\
\hline $\mathrm{GSH}(\mu \mathrm{mol} / \mathrm{gr} \mathrm{Hb})$ & $0.36 \pm 0.11$ & $0.23 \pm 0.04$ & 0.005 \\
\hline GST (U/gr Hb) & $2.82 \pm 1.92$ & $3.01 \pm 0.92$ & 0.811 \\
\hline CAT (kU/gr Hb) & $270.48 \pm 35.21$ & $145.41 \pm 8.66$ & 0.0001 \\
\hline \multirow[t]{2}{*}{$\mathrm{SOD}(\mathrm{U} / \mathrm{mg} \mathrm{Hb})$} & $3.21 \pm 0.70$ & $1.40 \pm 0.22$ & 0.0001 \\
\hline & $\begin{array}{c}\text { Control + } \mathrm{DDW}_{40} \\
(\mathrm{G} 3)(\mathrm{n}=6)\end{array}$ & $\begin{array}{c}\text { Diabetic }+\mathrm{DDW}_{40} \\
(\mathrm{G} 6)(\mathrm{n}=6)\end{array}$ & $\mathbf{P}$ \\
\hline Weight (gr) & $339.50 \pm 59.63$ & $270.67 \pm 72.41$ & 0.102 \\
\hline Food (gr/day) & $24.50 \pm 0.0$ & $33.96 \pm 0.0$ & 0.001 \\
\hline DDW (ml/day) & $39.13 \pm 0.0$ & $92.67 \pm 0.0$ & 0.001 \\
\hline Blood Glucose (mg\%) & $118.00 \pm 20.83$ & $391.17 \pm 119.71$ & 0.0001 \\
\hline $\mathrm{Hb}(\mathrm{gr} \%)$ & $2.42 \pm 0.07$ & $2.54 \pm 0.08$ & 0.021 \\
\hline LPO $(\mu \mathrm{mol} \mathrm{MDA} / \mathrm{gr} \mathrm{Hb})$ & $0.19 \pm 0.01$ & $0.18 \pm 0.01$ & 0.032 \\
\hline $\mathrm{GSH}(\mu \mathrm{mol} / \mathrm{gr} \mathrm{Hb})$ & $0.61 \pm 0.06$ & $0.91 \pm 0.06$ & 0.0001 \\
\hline GST (U/gr Hb) & $2.57 \pm 0.83$ & $2.82 \pm 1.52$ & 0.723 \\
\hline CAT (kU/gr Hb) & $164.05 \pm 23.36$ & $165.31 \pm 26.36$ & 0.932 \\
\hline $\mathrm{SOD}(\mathrm{U} / \mathrm{mg} \mathrm{Hb})$ & $2.23 \pm 0.23$ & $1.40 \pm 0.15$ & 0.0001 \\
\hline
\end{tabular}

Values are given as mean \pm standard deviation. Hb: Hemoglobin, LPO: Lipid peroxidation, GSH: Reduced glutathione, GST: Glutathione-S-transferase, CAT: Catalase, SOD: Superoxide dismutase, DDW: Deuterium depleted water, $\mathrm{DDW}_{30}$ : DDW consumption for 30 days, $\mathrm{DDW}_{40}$ : DDW consumption for 40 days. 
Table 2. Effect of DDW on food and water consumption, body weight, blood glucose levels and erythrocyte parameters in control groups.

\begin{tabular}{|c|c|c|c|c|}
\hline & \multicolumn{3}{|c|}{ Control Groups } & \multirow[b]{3}{*}{$\mathbf{P}$} \\
\hline & \multirow{2}{*}{$\begin{array}{c}\text { Tap Water Given Group } \\
\text { G1 }(\mathbf{n}=6)\end{array}$} & \multicolumn{2}{|c|}{ DDW Given Groups } & \\
\hline & & G2 $(n=6)$ & G3 $(n=6)$ & \\
\hline Weight (gr) & $351 \pm 79$ & $340 \pm 80$ & $340 \pm 60$ & 0.956 \\
\hline Food (gr/day) & $21.61 \pm 0.0$ & $26.39 \pm 0.0$ & $24.50 \pm 0.0^{b}$ & 0.0001 \\
\hline Water/DDW (ml/day) & $36.22 \pm 0.0$ & $45.17 \pm 0.0^{\mathrm{a}}$ & $39.13 \pm 0.0$ & 0.0001 \\
\hline Blood Glucose (mg\%) & $109.50 \pm 6.44$ & $97.33 \pm 11.96$ & $118.00 \pm 20.83$ & 0.104 \\
\hline $\mathrm{Hb}(\mathrm{gr} \%)$ & $2.18 \pm 0.13$ & $1.70 \pm 0.14^{\mathrm{a}}$ & $2.42 \pm 0.07^{a . b}$ & 0.0001 \\
\hline LPO $(\mu \mathrm{mol} \mathrm{MDA} / \mathrm{gr} \mathrm{Hb})$ & $0.28 \pm 0.04$ & $0.27 \pm 0.04$ & $0.19 \pm 0.01^{\mathrm{a} . \mathrm{b}}$ & 0.0001 \\
\hline $\mathrm{GSH}(\mu \mathrm{mol} / \mathrm{gr} \mathrm{Hb})$ & $0.41 \pm 0.11$ & $0.36 \pm 0.11$ & $0.61 \pm 0.06^{\mathrm{a} . \mathrm{b}}$ & 0.001 \\
\hline GST (U/gr Hb) & $2.75 \pm 1.53$ & $2.82 \pm 1.92$ & $2.57 \pm 0.83$ & 0.955 \\
\hline CAT (kU/gr Hb) & $216 \pm 17$ & $270 \pm 35^{a}$ & $164 \pm 23^{\text {a.b }}$ & 0.0001 \\
\hline $\mathrm{SOD}(\mathrm{U} / \mathrm{mg} \mathrm{Hb})$ & $1.91 \pm 0.50$ & $3.21 \pm 0.70^{\mathrm{a}}$ & $2.23 \pm 0.23^{c}$ & 0.002 \\
\hline
\end{tabular}

Values are given as mean \pm standard deviation. $\mathrm{Hb}$ : Hemoglobin, LPO: Lipid peroxidation, GSH: reduced glutathione, GST: Glutathione-S-transferase, CAT: Catalase, SOD: Superoxide dismutase, ${ }^{a} p<0.01$ significantly different from $G 1 ;{ }^{b} p<0.01$ and ${ }^{c} p<0.05$ significantly different from $G 2$, DDW: Deuterium depleted water.

Table 3. Effect of DDW on food and water consumption, body weight, blood glucose levels and erythrocyte parameters in diabetic groups.

\begin{tabular}{|c|c|c|c|c|}
\hline & \multicolumn{3}{|c|}{ Diabetic Group } & \multirow[b]{3}{*}{$\mathbf{P}$} \\
\hline & \multirow{2}{*}{$\begin{array}{c}\text { Tap Water Given Group } \\
\text { G4 }(\mathrm{n}=6)\end{array}$} & \multicolumn{2}{|c|}{ DDW Given Groups } & \\
\hline & & G5 $(n=8)$ & G6 $(n=6)$ & \\
\hline Weight (gr) & $294.50 \pm 85.54$ & $266.88 \pm 62.68$ & $270.67 \pm 72.41$ & 0.765 \\
\hline Food (gr/day) & $29.44 \pm 0.0$ & $28.92 \pm 0.0$ & $33.96 \pm 0.0^{d}$ & 0.0001 \\
\hline Water/ DDW (ml/day) & $89.11 \pm 0.0$ & $98.67 \pm 0.0^{b}$ & $92.67 \pm 0.0$ & 0.0001 \\
\hline Blood Glucose (mg\%) & $271 \pm 29$ & $204 \pm 27^{b}$ & $391 \pm 120^{c}$ & 0.002 \\
\hline $\mathrm{Hb}(\mathrm{gr} \%)$ & $2.87 \pm 0.16$ & $3.11 \pm 0.07^{\mathrm{a}}$ & $2.54 \pm 0.08^{b . c}$ & 0.0001 \\
\hline LPO ( $\mu$ mol MDA/gr Hb) & $0.23 \pm 0.02$ & $0.14 \pm 0.01^{b}$ & $0.18 \pm 0.01^{b . c}$ & 0.0001 \\
\hline GSH $(\mu \mathrm{mol} / g r \mathrm{Hb})$ & $24.52 \pm 7.16$ & $25.20 \pm 9.63$ & $79.14 \pm 12.19^{b}$ & 0.0001 \\
\hline GST (U/gr Hb) & $2.82 \pm 1.28$ & $3.01 \pm 0.92$ & $2.8 \pm 1.52$ & 0.946 \\
\hline CAT (kU/gr Hb) & $167.50 \pm 8.62$ & $145.41 \pm 8.66^{b}$ & $165.31 \pm 26.36$ & 0.004 \\
\hline $\mathrm{SOD}(\mathrm{U} / \mathrm{mg} \mathrm{Hb})$ & $1.24 \pm 0.41$ & $1.40 \pm 0.22$ & $1.40 \pm 0.15$ & 0.684 \\
\hline
\end{tabular}

cant changes in the other erythrocyte parameters. Erythrocyte hemoglobin values decreased significantly in 30 days DDW drinking group (G2) and increased significantly in 40 days DDW drinking group (G3) compared to tap water drinking group (G1). LPO levels in 40 days DDW drinking group were significantly lower than those in both tap water and 30 days DDW drinking groups. In contrast to LPO levels, GSH levels increased significantly in 40 days drinking DDW group compared to tap water and 30 days DDW drinking groups. CAT and SOD activities were significantly increased by DDW consumption first, however, later than they were decreased by prolonged DDW consumption (Table 2). 


\section{Effect of DDW in Diabetic Group}

DDW consumption did not cause any change in weights in diabetic groups $(\mathrm{G} 4, \mathrm{G} 5, \mathrm{G} 6)$. Food consumption rose significantly in 40 days DDW drinking diabetic group (G6) compared to 30 days DDW drinking diabetic group (G5). Also, DDW consumption was much more than those in tap water drinking diabetic group. Blood glucose level was significantly lower in 30 days DDW drinking diabetic group than those of tap water drinking and 40 days DDW drinking diabetic group (Table 3 ).

DDW consumption did not cause any significant change in erythrocyte GST and SOD activities in diabetic groups. Hemoglobin value increased in 30 days DDW drinking diabetic group (G5), in contrast, it decreased significantly in 40 days DDW drinking diabetic group (G6) compared to tap water drinking diabetic group (G4). Erythrocyte LPO levels decreased significantly in 30 and 40 days DDW drinking diabetic group compared to tap water drinking diabetic group. DDW consumption increased the GSH level significantly in 40 days DDW drinking diabetic group (G6) compared to those of other diabetic groups (G4 and G5). Consumption of DDW caused a significant decrease in CAT activity in 30 days DDW drinking diabetic group compared to those of tap water drinking diabetic group. However, CAT activity in 40 days drinking DDW group (G6) was not significantly different from tap water drinking group (G4) (Table 3).

\section{DISCUSSION}

Increased oxidative stress, altered lipid peroxidation, and decreased antioxidant enzymes activities are important risk factors for diabetes $(16,27,28)$. Diet undoubtedly plays a key role as a chemopreventive agent against diabetes as well as various other diseases and optimizing the diet has a preventative function. Erythrocytes were selected as the experimental material in this study, as they interact with oxygen, exposed to oxidative stress and are affected more than other cells from hyperglycemia in diabetes. Moreover, there is no data related with the erythrocytes and DDW consumption in diabetes in the concerning literature. Therefore, in the present study, the effect of DDW consumption on LPO, GSH levels and SOD, CAT, GST activities of erythrocytes were examined in experimental diabetes in rats.

Hyperglycemia and weight loss are the common features of STZ induced experimental diabetes unless it is treated (29-31). Thirty five $\mathrm{mg} / \mathrm{kg}$ of STZ injection may raise blood glucose level around $130 \mathrm{mg} \%$ and $175 \mathrm{mg} \%$ after 7 days and 28 days, respectively (30-32). However, in the present study, blood glucose levels were found to be more than $175 \mathrm{mg} \%$ in diabetic groups at the end of the experiment (at 30 days). Weight loss in the diabetic groups was not significant which is in contrast with other studies (29-31). The reasons for this finding could be the differences in dose of STZ, experimental period, animal species or genus in different studies.

Long-term high blood glucose concentration increases oxidative stress via free radical formation in diabetes. This is tried to be overcome by the antioxidant defense system. Therefore, antioxidant system parameters are reduced in uncontrolled di- abetes $(16,27,33)$. Oxidative stress affects not only some organs such as the pancreas, kidney, eyes and skin, but also the vascular structure and blood cells.

There were conflicting findings about antioxidant parameters in diabetes. The activities of the antioxidant enzymes have been found to be increased, decreased or not to be changed in those studies (34-36). This may be due to the differences between the studies in point of duration of diabetes, investigative parameters and tissues analyzed.

In some studies, erythrocyte CAT enzyme activity was found to be increased in diabetes (37-39). In contrast with these studies, it has been reported that erythrocyte LPO level and GST activity increased, GSH level and SOD, CAT and GPx enzyme activities decreased in diabetes (33,38-46). While the increase in CAT activity was attributed to high level free radicals and their harmful effects on cell membrane proteins and lipids, the decrease in SOD, CAT, and GPx activities and the increase in MDA level were attributed to the increased oxidative stress and decreased antioxidant reserve during hyperglycemia. In the present study, diabetic erythrocyte antioxidant parameters (GSH, SOD, CAT) decreased when compared with the controls, however, in contrast with them, there was a significant decrease in diabetic LPO levels. Similar to the study by Tatsuki et al. (32), this may be due to the suppression of MDA increase by the effect of antioxidants developed in shorter time. Tatsuki et all found that finding at the end of the $7^{\text {th }}$ week, which is 3 weeks longer than our diabetes model.

Nowadays, different natural products and sources are used for the treatment of diabetes. In the present study, we used DDW for this purpose. It has been reported that deuterium is necessary for human, animal and plant cell growth; $(5,7,8)$ DDW inhibits cell proliferation and induces apoptosis and reduces tumor growth rate; $(2,7,8,47)$ affects vascular reactivity; $(48)$ has radioprotective and immunostimulating effects; (49) and a slight increase in the deuterium concentration stimulates cell growth (8).

The proposed action mechanisms for DDW can be summarized as follows: It has been supposed that cells have a D-H metabolism which regulates the $\mathrm{D} / \mathrm{H}$ ratio in cells and, through this, a number of other processes too. The $\mathrm{pH}$ regulation of cells, and processes happening through the cell membrane might be connected with the change in the intracellular $\mathrm{D} / \mathrm{H}$ ratio. The $\mathrm{D} / \mathrm{H}$ ratio can increase in the cells if one of the $\mathrm{H}^{+}$transport systems ( $\mathrm{H}$-ATPase, $\mathrm{Na}^{+} / \mathrm{H}^{+}$antiport system) gets activated in the membrane. This process prefers $\mathrm{H}^{+}$, thus $\mathrm{H}^{+}$and $\mathrm{D}^{+}$get ejected from the cell or organelle (e.g. mitochondria) not in proportion to their ratio of occurrence. A wide variety of external signals enhances the affinity of the antiporter for $\mathrm{H}^{+}$at neutral $\mathrm{pH}$, leading to alkalinization of the cells $(2,8,10,11)$.

During several external effects, cells are able to adapt to this new condition. Deuterium depletion induces a stress in cells. While healthy cells quickly adapt to deuterium depletion, the other cells are unable to do so or most adapt much more slowly (8). 
Cell division is triggered by the change of the $\mathrm{D} / \mathrm{H}$ ratio. Deuterium is important for cell proliferation and through deuterium depletion in the body, either the conditions for cell division do not exist, or the cell can only achieve this ratio considerably later. It has also been shown that deuterium depletion inhibits cyclooxygenase- 2 activity $(8,11)$.

Moreover, it has been reported that facilitative glucose transporters (GLUTs) act as a transmembrane pathway for water flow (50).

There are a very limited number of studies about DDW and diabetes in the literature. While investigating anti-cancer effects of DDW it has been observed that the state of diabetes mellitus was improved in some patients having tumors associated diabetes mellitus. After drinking DDW their blood glucose levels that had earlier been fluctuating became steady or the high blood glucose levels decreased more or less to normal range. The positive effect of DDW on blood glucose was also found in patients with type I and type II diabetics in another study (5). Tatsou et al. (21) and Alekseevich et al. (20) found that DDW decreased blood glucose levels in diabetics.

In the present study, the blood glucose level significantly decreased in 30 days DDW drinking diabetic group, but it significantly increased in 40 days DDW drinking diabetic group compared to tap water drinking diabetic group. The reason for the decrease in blood glucose in 30 days drinking DDW diabetic group may be due to the enhanced glucose uptake caused by DDW, and the later increase in blood glucose may be due to the adaptation of the cell to D-depletion. It seems that consumption time and concentration of deuterium are important factors for its effect. Further investigation is necessary to clarify the mechanism of action of DDW on blood glucose.

DDW consumption was much higher in both control and diabetic groups than those in tap water drinking groups in the present study. Moreover, food consumption was also high in DDW drinking groups. This finding can also be contributed to the unexpected weight increase in diabetics and controls.

In the present study 30 days and 40 days DDW (85 ppm) consumption have different effects on erythrocyte antioxidant and oxidant system parameters. The net effect had been found on GSH. DDW caused an increase in GSH levels in both of control and diabetic groups. GSH plays a central role in antioxidant defense by detoxifying reactive oxygen species directly or in a GPx catalyzed mechanism. One of the above mechanisms may be responsible for the significant increase in erythrocyte GSH content.

Various clinical and experimental studies with DDW have been conducted to date. According to the results of these studies, it has been suggested that DDW consumption regulates cellular respiration, increases cellular energy, has antioxidant activity, hypoglycemic and antitumor effect, has a positive effect on mental functions, radioprotective effect, detoxification and the immune system (48,51-59).
In conclusion, DDW, by increasing erythrocyte GSH levels, can be protective against diabetic complications due to the oxidative stress. The period of use of DDW and consumption dose of DDW could affect the results of the experiments. In order to determine the mechanism of action, the useful dosage and the application period of DDW, more research need to be done. We believe that the present study will enlighten future studies.

Ethics Committee Approval: The study was approved by the Animal Ethics Committee of Marmara University (Registration no: 52.2008. mar).

Peer-review: Externally peer-reviewed.

Author Contributions: Concept - A.Ç., A.Y., T.Y.; Supervision - A.Ç., A.Y., T.Y.; Materials - A.Ç., A.Y., T.Y.; Data Collection and/or Processing - A.Ç., A.Y., T.Y.; Analysis and/or Interpretation - A.Ç., A.Y., T.Y.; Literature Search - A.Ç., A.Y., T.Y.; Writing - A.Ç., A.Y., T.Y.; Critical Reviews - A.Ç., A.Y., T.Y.

Conflict of Interest: The authors have no conflict of interest to declare.

Financial Disclosure: This study was supported by a grant from Scientific Research Project Department of Marmara University (Project No: SAĞ-C-YLP-171108-0261).

Etik Komite Onayı: Bu çalışma Marmara Üniversitesi Hayvan Etiği Komitesi tarafından onaylanmıştır (Kayıt no: 52.2008.mar).

Hakem Değerlendirmesi: Dış bağımsız.

Yazar Katkıları: Fikir - A.Ç., A.Y., T.Y.; Denetleme A.Ç., A.Y., T.Y.; Gereçler - A.Ç., A.Y., T.Y.; Veri Toplanması ve/veya İşlemesi - A.Ç., A.Y., T.Y.; Analiz ve/veya Yorum - A.Ç., A.Y., T.Y.; Literatür Taraması - A.Ç., A.Y., T.Y.; Yazan A.Ç., A.Y., T.Y.; Eleştirel İnceleme - A.Ç., A.Y., T.Y.

Çıkar Çatışması: Yazarlar çıkar çatışması bildirmemişlerdir.

Finansal Destek: Bu çalışma Marmara Üniversitesi Bilimsel Araştırma Projesi Bölümü tarafından desteklenmiştir (Proje No: SAĞ-CYLP-171108-0261).

\section{REFERENCES}

1. Collins CJ, Bowman NS (Eds). Effects In Chemical Reactions. Van Nostrand Reinhold, York, pp. 286-363, 1971.

2. Wiberg KB. The Deuterium Isotope Effect. Chem Rev. 1955, 55: 713-43. [CrossRef]

3. Jancso G, Van Hook WA. Condensed Phase Isotope Effects: Especially Vapor Pressure. Isotope Effects 1974; 74: 689-750. [CrossRef]

4. Rundel PW, Ehleringer JR, Nagy KA: Stable In Ecological Research. Springer, York, pp. 7-9, 1988. [CrossRef]

5. Blaga L. The Deuterium content of human metabolic fluids in relation with human metabolic processes (in Romania), IFA-Bucuresti, Scientific Report, 1978, 1-4.

6. Berdea P, Cuna S, Cazacu M, Tudose M. Deuterium Variation of Human Blood Serum. Studia Universitatis Babeş-Bolyai, Physica, Special Issue $2001 ; 256-8$.

7. Somlyai G, Jancso G, Jakli G, Vass K, Barna B, Lakics V, Gaal T. Naturally occuring deuterium is essential for the normal growth rate of cells. FEBS Letters 1993; 317: 1-4. [CrossRef] 
8. Somlyai G. Defeating Cancer. The Biological Effect of Deuterium Depletion by Gabor Somlyai HYD Ltd. for Research and Development ISBN: 0-7596-9261-0;2002.

9. Somlyai G, Laskay G, Berkenyi T, Galbacs Z, Galbacks G, Kiss SA, Jakli GY, Jancso G. The Biological Effects of Deuterium-Depleted Water, a Possible New Tool in Cancer Therapy. Journal of Oncology 1998; 30(4): 91-4.135.

10. Cong F, Zhang Y, Sheng H, Ao Z, Zhang S, Wang J. Deuterium-depleted water inhibits human lung carcinoma cell growth by apoptosis. Experimental and Therapeutic Medicine 2010; 1: 277-83. [CrossRef]

11. Somlyai G, Molnar M, Laskay G, Szabo M, Berkenyi T, Guller I, Kovaks $A$. Biological significance of naturally occurring deuterium: the antitumor effect of deuterium depletion. Orvosi Hetilap 2010; 5; 151(36): 1455-60. [CrossRef]

12. Keempels K, Somlyi I, Somlyai G. A retrospective evaluation of the effects of deuterium depleted water consumption on 4 patients with brain metastases from lung cancer. Integrative Cancer Therapies 2008; 7(3): 172-81. [CrossRef]

13. Katz JJ, Crespi HL, Hasterlik RJ, Thomson JF, Finkel AJ. Some Observations on Biological Effects of Deuterium, with Special Reference to Effects on Neoplastic Processes. Journal of the National Cancer Institute 1957; 18(5): 641-58.

14. Synergistic Effects of Deuterium Oxide and Gemcitabine in Human Pancreatic Cancer Cell Line, Cancer Letter 2008; 259: 231-9. [CrossRef]

15. Bahk JY, Lee JH, Chung HS, LeeHY, Chung BC, Park MS, Min SK, Kim MO. Anticancer Effect of Deuterium Oxide on a Bladder Cancer Cell Related to $\mathrm{Bcl}-2$ and Bax. Journal of Indian Engineering Chemistry 2007; 13(4): 501-7.

16. MaritimAC, Sanders RA, Watkins JB. Diabetes, Oxidative Stress and Antioxidants: A Review. Journal of Biochemical and Molecular Toxicology 2003; 17(1): 24-38. [CrossRef]

17. Nwose EU, Jelinek HF, Richards RS, Kerr PG. Erythrocyte oxidative stress in clinical management of diabetes and its cardiovascular complications. British Journal of Biomedical Sciences 2007; 64(1): 35-43. [CrossRef]

18. Shin S, Ku Y, Babu N, Singh M. Erythrocyte deformability and its variation in diabetes mellitus. Indian Journal of Experimental Biology 2007; 45(1): 121-8.

19. Leoncini S, Rossi V, Signorini C, Tanganelli I, Comporti M, Ciccoli L. Oxidative stress, erythrocyte ageing and plasma non-proteinbound iron in diabetic patients. Free Radical Research 2008; 42(8): 716-4. [CrossRef]

20. Alekseevich TA et al. Method for treatment of patients with diabetes mellitus, 01-10(ru2270017), 2006.

21. Tatsuo U, Kunihiro S. Treatment of Cancer, Diabetes Mellitus, Leukemia, Aplastic Anemia and Insomnia, Treatment and Prevention of Severe Acute Respıratory Syndrome (Sars), Rejuvenation, Activation of Cell and Promotion of Increase of Immune Cell by Soy Sauce Prepared by Using Deuterium-Attrited Water (Super Light Water) as Raw Material, and Method for Producing The Same. Internatl Scient KK. A23L1/238; 12-24 (JP2004357678), 2004.

22. Habig WH, Jacoby WB. Assays for differentiation of glutathione-s- transferases. Methods in Enzymology 1981; 77: 398-405. [CrossRef]

23. Aebi H.: Catalase invitro. In: Methods of enzymatic Analysis, 2nd Edition, vol.2, Bergmeyer HU (Ed), FL., pp.121-126.

24. Mylorie AA, Collins H, Umbles C, Kyle J. Erythrocyte superoxide dismutase activity and other parameters of cupper status in rats ingesting lead acetate. Toxicology and Applied Pharmacology 1986; 82: 512-520. [CrossRef]
25. Ledwozyw A, Michalak D, Stepien A, Kadziolka A. The relationship between plasma triglycerides, cholesterol, total lipids and lipid peroxidation products during human atherosclerosis. Clinica Chimica Acta 1986; 155; 275-83. [CrossRef]

26. Beutler E.: Glutathione in Red Cell Metabolism: A manual of Biochemical methods, 2nd ed.: Grune and Stratton, NY., pp.112-114.

27. Watkins PJ. ABC of Diabetes. 5th ed, BMJ Publishing Group Ltd, London, p.2-3,2003.

28. Pietropaolo M, Trucco M.Genetics of Type I Diabetes. In: Type 1 Diabetes. Ed: Sperling MA, Humana Press Inc, New Jersey, p.28, 2003.

29. Yarat A, Yanardag R, Tunalı T, Sacan O, Gursoy F, Emekli N, Ustuner A, Ergenekon G. Effects of glibornuride versus metformin on eye lenses and skin in experimental diabetes. Arzneimittel Forschung Drug Research 2006; 56(7): 541-6. [CrossRef]

30. Szkudelski T. The mechanism of alloxan and streptozotocin action in B cells of the rat pancreas. Physiological Research 2001; 50: 53646.

31. Junod A, Lambert AE, Stauffacher W, Renold AE. Diabetogenic action of streptozotocin: Relation of dose to metabolic response. The Journal of Clinical Investigation 1969; 48: 2129-39. [CrossRef]

32. Tatsuki R, Satoh K, Yamamoto A, Hoshi K, Ichihara K. Lipid peroxidation in the pancreas and other organs in streptozotocin diabetic rats. Japanese Journal Pharmacology 1997; 75: 267-73. [CrossRef]

33. Coşkun O, Ocakcı A, Bayraktaroğlu T, Kanter M. Exercise training prevents and protects streptozotocin-induced oxidative stress and $\beta$-cell damage in rat pancreas. Tohoku Journal Experimental Medicine 2004; 203: 145-54. [CrossRef]

34. Atkinson MA, Eisenbarth GS. Type 1 diabetes: new perspectives on disease pathogenesis and treatment. Lancet 2001; 358: 221-9. [CrossRef]

35. Griesmacher A, Kindhauser M, Andert SE, Schreiner W, Tomo C, Kroebl P, Pietschmann P, Prager R, Schnack C, Schernthaner G, Mueller M. Enhanced Serum levels of thiobarbituric acid - reactive substances in diabetes mellitus. American Journal of Medicine 1995; 98(5): 469-75. [CrossRef]

36. Giugliano D, Ceriello A, Paolisso G. Oxidative stress and diabetic vascular complications. Diabetes Care 1996; 19: 257-67. [CrossRef]

37. Qujeq D, Rezvani T. Catalase (antioxidant enzyme) activity in streptozotocin-induced diabetic rats. International Journal of Diabetes and Metabolism 2007; 15: 22-4.

38. Sekar N, Kanthasamy A, William S, Balasubramaniyan N, Govindasamy S. Antioxidant effect of vanadate on experimental diabetic rats. Acta Diabetologica Latina 1990; 27: 285-93. [CrossRef]

39. Mukherjee B, Mukherjee JR, Chatterjee M. Lipid peroxidation, glutathione levels and changes in glutathione-related enzyme activities in streptozotocin-induced diabetic rats. Immunology and Cell Biology 1994; 72: 109-14. [CrossRef]

40. Ramakrishna V, Jailkhani R. Evalution of oxidative stress in insulin dependent diabetes mellitus (IDDM) patients. Diagnostic Pathology 2007; 2: 22. [CrossRef]

41. Peuchant E, Brun JL, Rigalleau V, Dubourg L, Thomas MJ, Daniel $J Y$, Leng JJ, Gin H. Oxidative and antioxidative status in pregnant women with either gestational or type 1 diabetes. Clinical Biochemistry 2004; 37: 293-8. [CrossRef]

42. Bhatia S, Shukla R, Madhu SR, Gambhir JK, Prabhu KM. Antioxidant status, lipid peroxidation and nitric oxide end product in patients of type 2 diabetes mellitus with nephropathy. Clinical Biochemistry 2003; 36: 557-62. [CrossRef]

43. Memişoğulları R, Taysı S, Bakan E, Capoğlu I. Antioxidant status and lipid peroxidation in type II diabetes mellitus. Cellular Biochemical Function 2003; 21: 291-6. [CrossRef] 
44. Sailaja YR, Baskar R, Saralakumari D. Antioxidant status during maturation of reticulocytes to erythrocytes in type 2 diabetics. Free Radical Biology and Medicine 2003; 35(2): 133-9. [CrossRef]

45. Vural H, Sabuncu T, Arslan SO, Aksoy N. Melatonin inhibits lipid peroxidation and stimulates the antioxidant status of diabetic rats. Journal of Pineal Research 2001; 31: 193-8. [CrossRef]

46. Chandramohan G, Al-Numair KS, Pugalendi KV. Restoration of altered plasma, erythrocyte and liver antioxidant levels. International Journal of Integrative Biology 2009; 5(3): 176-81.

47. Bild W, Nastasa V, Haulica I. In vivo and in vitro research on biological effects of deuterium-depleted water: 1. Influence of deuterium-deoleted water on cultured cell growth. Romanian Journal of Physiology 2004; 41(1-2): 53-67.

48. Haulica I, Peculea M, Stefanescu I, Titescu G, Todiras M, Bild W. Effects of heavy and deuterium-depleted water on vascular reactivity. Romanian Journal of Physiology 1998; 35(1-2): 25-32.

49. Bild W, Stefanescu I, Haulica I, Lupusoru C, Titescu G, Iliescu R, Nastas V. Research concerning the radioprotective and immunostimulating effects of deuterium depleted water. Romanian Journal of Physiology 1999; 36(3-4): 205-18.

50. Loike JD, Caol L, Kuang K, Vera JC, Silverstein SC, Fischbarg J. Role of facilitative glucose transporters in diffusional water permeability through J774 cells. Journal of Genetic Physiology 1993; 102(5): 897-906. [CrossRef]

51. Kovács A, Guller I, Krempels K, Somlyai I, Jánosi I, Gyomgyi Z, Szabó I, Ember IGS (2011) Deuterium depletion may delay the progression of prostate cancer. J Cancer Ther 2011; 2: 548-56. [CrossRef]

52. Ávila DS, Somlyai G, Somlyai I, Aschner M. Anti-aging effects of deuterium depletion on $\mathrm{Mn}$-induced toxicity in a C. Elegans Model. Toxicol Lett 2012; 211: 319-24. [CrossRef]
53. Gyöngyi Z, Budan F, Szabo I, Ember I, Kiss I, Krempels K, Somlyai I, Somlyai G. Deuterium depleted water effects on survival of lung cancer patients and expression of $\mathrm{Kras}, \mathrm{BCl} 2$, and Myc genes in Mouse lung. Nutr Cancer 2013; 65(2): 240-6. [CrossRef]

54. Mladin C, Ciobica A, Lefter R, Popescu A, Bild W. Deuterium depleted water has stimulating effects on long-term memory in rats. Neurosci Lett 2014; 583: 154-8. [CrossRef]

55. Soleyman-Jahi S, Zendehdel K, Akbarzahed K, Haddadi M, Amanpour S, Muhammadnejad S. In vitro Assessment of antineoplastik effects of döteryum depleted water. Asian Pac J Cancer Prev 2014; 15(5): 2179-83. [CrossRef]

56. Lisitsyn AB, Baryshev MG, Basov AA, Barysheva EV, Bykov IM, DyDykin AS, Tekutskaia EE, Timakov AA, Fedulova LV, Chernukha IM, Dzhimak SS. Influence of deuterium depleted water on the organism of laboratory animals in various functional conditions of nonspecific protective system. Biofizika 2014; 59(4): 757-65. [CrossRef]

57. Strekalova T, Evans M, Chernopiatko A, Couch Y, Costa-Nunes J, Cespuglio R, Chesson L, Vignisse J, Steinbusch HW, Anthony DC, Pomytkin I, Lecsh KP. Deuterium content of water increases depression susceptibility: The potential role of a serotonin-related mechanism. Behavioural Brain Res 2015; 277: 237-44. [CrossRef]

58. Boros LG, D'Agostino DP, Katz HE, Roth JP, Meuillet EJ, Somlyai G. Submolecular regulation of cell transformation by deuterium depleting water exchange reactions in the tricarboxylic acid substrate cycle. Med Hypothesis 2016; 87: 69-74. [CrossRef]

59. Dzhimak SS, Basov AA, Baryshev MG. Content of deuterium in biological fluids and organs: Influence of deuterium depleted water on D/H gradient and the process of adaptation. Doki Biochem Biophys 2015; 465(1): 370-373. [CrossRef] 